\title{
Manfaat Dana Bantuan Operasional Sekolah (Bos) Terhadap Mutu Proses Pembelajaran
}

\author{
Nurul Fatonah \\ Universitas Garut \\ nurulfatonah@uniga.ac.id
}

\begin{abstract}
Abstrak
Dana mempunyai peranan yang sangat penting terhadap proses pembelajaran karena merupakan salah satu faktor yang menunjang mutu pembelajaran. Penelitian ini bertujuan untuk mengetahui pengaruh manfaat dana BOS terhadap mutu proses pembelajaran. Penelitian berlokasi di SDIT Assalam Garut Kota mengingat aktualisasi permasalahan yang diteliti serta ketersediaan pihak sekolah dalam mendukung kelancaran penelitian. Penelitian dilakukan dengan menggunakan teknik analisis deskriptif inverensial yaitu menggambarkan kondisi sebenarnya dengan statistika sebagai alat ukur dalam pengujiannya. Dengan pengambilan data menggunakan metode observasi, wawancara, studi pustaka dan angket Analisis data dilaksanakan dengan cara mengidentifikasi data yang tersusun dalam tabel berdasarkan klasifikasi masalah dan penafsiran tabel - tabel dengan menggunakan skala interval. Dan selanjutnya untuk menghitung nilai korelasi dengan menggunakan rank spearman. Adapun jumlah respondennya yaitu 22 orang yang merupakan pendidik yang sedang mengajar. Hasil yang diperoleh diambil kesimpulan bahwa terdapat korelasi atas pengaruh kontribusi manfaat dana bantuan operasional sekolah (Variabel X) terhadap mutu proses pembelajaran (Variabel Y) dengan nilai korelasi sebesar 0,52. Angka ini termasuk kedalam kriterai cukup kuat. Dengan demikian manfaat dana BOS memberikan pengaruh cukup kuat terhadap mutu proses pembelajaran. Adapun besarnya kontribusi pengaruh kontribusi manfaat dana BOS terhadap mutu proses pembelajaran sebesar $27 \%$. Sedangkan sisanya sebesar $73 \%$ ditentukan oleh variabel lain yang tidak diteliti.
\end{abstract}

Kata kunci: Bantuan Operasional Sekolah, Dana BOS, Mutu Belajar 


\section{Pendahuluan}

Pendidikan merupakan persoalan penting bagi semua umat, pendidikan selalu menjadi tumpuan harapan untuk mengembangkan individu masyarakat. Pendidikan merupakan alat untuk memajukan peradaban, mengembangkan masyarakat dan membuat generasi mampu berbuat banyak bagi kepentingan mereka. Tujuan pendidikan sama dengan tujuan hidup bangsa, yaitu melahirkan individu keluarga dan masyarakat yang shaleh serta menumbuhkan konsep-konsep kemanusiaan yang baik diantara umat manusia dalam mencapai suasana saling pengertian nasional, yakni konsep-konsep yang sesuai dengan budaya, peradaban dan warisan umat serta pandangannya tentang alam, manusia dan hidup (Aly, 2000:1).

Untuk memajukan kehidupan mereka itulah maka pendidikan menjadi sarana utama yang perlu dikelola secara sistematis dan konsisten. Manusia adalah makhluk yang dinamis dan bercita-cita ingin meraih kehidupan yang sejahtera dan bahagia dalam arti yang luas baik jasmani maupun rohani, duniawi dan ukhrowi. Namun cita-cita demikian itu sendiri tidak berusaha keras meningkatkan kemampuannya seoptimal mungkin melalui proses pendidikan, karena proses pendidikan merupakan suatu kegiatan yang bertahap untuk mencapai suatu tujuan.

Di Indonesia kebijakan pembangunan di bidang pendidikan dalam kurun waktu 2004-2009 meliputi akses rakyat terhadap pendidikan yang lebih berkualitas melalui peningkatan pelaksanaan Wajib Belajar Pendidikan Dasar Sembilan Tahun dan pemberian akses yang lebih besar kepada kelompok masyarakat yang selama ini kurang dapat menjangkau layanan pendidikan, seperti masyarakat miskin, masyarakat yang tinggal di daerah terpencil, ataupun masyarakat penyandang cacat (Depag, 2005:1).

Salah satu alasan rendahnya partisipasi pendidikan khususnya pada kelompok miskin adalah tingginya biaya pendidikan baik biaya langsung maupun tidak langsung. Biaya langsung meliputi iuran sekolah, buku, seragam dan alat tulis, sementara biaya tidak langsung meliputi biaya transportasi, kursus, uang saku dan lain-lain (Riyadi, 2007:6).

Keuangan dan pembiayaan merupakan salah satu komponen pendidikan yang secara langsung menunjang efektivitas dan efisiensi pengelolaan pendidikan. Hal tersebut menuntut kemampuan sekolah untuk merencanakan, melaksanakan dan mengevaluasi serta mempertanggungjawabkan pengelolaan dana secara transparan kepada masyarakat dan pemerintah (Riyadi, 2007:6). 
Dalam penyelenggaraan pendidikan, keuangan dan pembiayaan merupakan potensi yang sangat menentukan dan merupakan bagian yang tak terpisahkan dalam kajian manajemen pendidikan. Komponen keuangan dan pembiayaan pada suatu sekolah merupakan komponen produksi yang menentukan terlaksananya kegiatan proses belajar mengajar di sekolah bersama komponen - komponen yang lain. Dengan kata lain setiap kegiatan yang dilakukan sekolah memerlukan biaya. Komponen keuangan dan pembiayaan ini perlu dikelola sebaiknya - baiknya agar dana - dana yang ada yang dapat dimanfaatkan secara optimal untuk menunjang tercapainya tujuan pendidikan (Mulyasa, 2003:47).

Sejak tahun 2004 melalui dana Bantuan Operasional Sekolah (BOS) peserta didik tingkat pendidikan dasar yaitu SD/sederajat dan SMP/sederajat telah dibebaskan dari beban biaya operasional sekolah. Bantuan Operasional Sekolah yang langsung dikelola oleh sekolah meliputi biaya untuk pendaftaran, iuran bulanan sekolah, biaya ujian, bahan dan biaya praktek. Biaya di atas tersebut tidak termasuk biaya investasi seperti penyediaan sarana prasarana sekolah, gaji guru dan tenaga kependidikan lainnya, serta biaya peningkatan mutu guru (Sugeng, 2007:6).

BOS memang sangat membantu bagi peserta didik dan sekolah. Bahkan menurut survey Bank Dunia tentang School Based Management (2010) ternyata BOS dapat menurunkan tingkat drop out sampai $81 \%$, meningkatkan transisi peserta didik SD ke SMP sampai 90\%, meningkatkan masuknya peserta didik-peserta didik miskin ke sekolah sampai 74\% dan meningkatkan prestasi peserta didik $90 \%$. Survey ini dilakukan ketika BOS baru menutup $80 \%$ biaya operasional. Oleh karena itu dengan BOS menjadi 100\% dari biaya operasional sekolah di tahun 2012 ditambah BOSDA, dan partisipasi masyarakat, maka semakin optimis dapat meningkatkan kualitas pendidikan dasar secara nyata (Radar Garut, 2013).

Di berbagai daerah termasuk kecamatan Garut Kota sejak digulirkannya dana BOS hingga kini bermunculan sekolah-sekolah baru didaerah terpencil sekalipun yang tentu berdampak bagi bertambahnya partisipasi masyarakat dalam menyekolahkan anaknya. Salah satunya adalah SDIT Assalam yang berdiri sejak tahun 2006, sejak berdirinya sekolah tersebut mendapat kucuran dana BOS. Namun meskipun pembiayaanna ditunjang dari dana BOS namun mutu proses pembelajarannya masih kurang. 
Untuk mengkaji lebih dalam mengenai pengaruh manfaat dana BOS terhadap mutu proses pembelajaran maka peneliti tertarik untuk meneliti lebih lanjut mengenai keterkaitan antar kedua variabel tersebut. Penelitian yang akan laksanakan dengan judul "Pengaruh manfaat Dana Bantuan Operasional Sekolah Terhadap Mutu Proses Pembelajaran" (Penelitian di SDIT Assalam Kecamatan Garut Kota Kabupaten Garut).

\section{Metode Penelitian}

Penelitian ini menggunakan tekhnik analisis deskriptif inferensial. Yaitu penelitian yang diambil berdasarkan fenomena yang terjadi dengan mengambil kesimpulan dari data hasil sampel dengan menggunakan uji statistik. Dengan mendekripsikan atau menggambarkan fenomena-fenomena yang ada, baik fenomena yang bersifat alamiah ataupun rekayasa manusia.

Dalam penelitian deskripstif, peneliti tidak melakukan manipulasi atau memberikan perlakuan tertentu terhadap variabel atau merancang sesuatu yang diharapkan terjadi pada variabel, tetapi semua kegiatan, keadaan, kejadian, aspek, komponen atau variabel berjalan sebagimana adanya. Tanpa penelitian pun semua kegiatan, keadaan, komponen variabel berjalan seperti itu. Penelitian ini berkenan dengan keadaan atau kejadian-kejadian yang biasa berjalan. Satu-satunya unsur manipulasi atau perlakuan yang diberikan hanyalah penelitian itu sendiri, yang dilakukan melalui observasi, wawancara, pengedaran angket atau study dokumentasi. Penelitian deskriptif tidak berhenti pada pengumpulan data, pengorganisasian, analis dan penarikan interprestasi serta penyimpulan, tetapi dilanjutkan dengan pembandingan, mencari kesamaan-perbedaan dan hubungan kausal dalam berbagai hal. Penemuan makna adalah fokus dari keseluruhan proses.

\section{Hasil dan Pembahasan}

Hasil analisis deskriptif terhadap pengaruh manfaat dana BOS adalah sebagai berikut :

\begin{tabular}{|c|c|c|c|c|}
\hline No & Item Pertanyaan & $\begin{array}{c}\text { Jumlah } \\
\text { Skor }\end{array}$ & $\begin{array}{c}\text { Persentase } \\
(\mathbf{\%})\end{array}$ & Kriteria \\
\hline 1 & $\begin{array}{l}\text { Selama ini di SDIT Assalam } \\
\text { penggunaan dana BOS untuk } \\
\text { pengembangan perpustakaan }\end{array}$ & 69 & 63 & Cukup Baik \\
\hline
\end{tabular}




\begin{tabular}{|c|c|c|c|c|}
\hline 2 & $\begin{array}{l}\text { Selama ini di SDIT Assalam } \\
\text { penggunaan dana BOS untuk } \\
\text { pembelajaran dan ekstrakulikuler } \\
\text { peserta didik }\end{array}$ & 57 & 52 & Cukup Baik \\
\hline 3 & $\begin{array}{l}\text { Selama ini di SDIT Assalam } \\
\text { penggunaan dana BOS untuk } \\
\text { kegiatan ulangan dan ujian }\end{array}$ & 72 & 65 & Cukup Baik \\
\hline 4 & $\begin{array}{l}\text { Selama ini di SDIT Assalam } \\
\text { penggunaan dana BOS untuk } \\
\text { pembelian bahan-bahan habis } \\
\text { pakai }\end{array}$ & 87 & 79 & Baik \\
\hline 5 & $\begin{array}{l}\text { Selama ini di SDIT Assalam } \\
\text { penggunaan dana BOS untuk } \\
\text { perawatan sekolah }\end{array}$ & 79 & 72 & Baik \\
\hline 6 & $\begin{array}{l}\text { Selama ini di SDIT Assalam } \\
\text { penggunaan dana BOS untuk } \\
\text { pembayaran honorarium bulanan } \\
\text { guru honorer dan tenaga } \\
\text { kependidikan honorer }\end{array}$ & 88 & 80 & Baik \\
\hline 7 & $\begin{array}{l}\text { Selama ini di SDIT Assalam } \\
\text { penggunaan dana BOS untuk } \\
\text { pengembangan profesi guru }\end{array}$ & 79 & 72 & Baik \\
\hline 8 & $\begin{array}{l}\text { Selama ini di SDIT Assalam } \\
\text { penggunaan dana BOS untuk alat } \\
\text { peraga/media pembelajaran. }\end{array}$ & 89 & 81 & Baik \\
\hline 9 & $\begin{array}{l}\text { Selama ini di SDIT Assalam ada } \\
\text { tingkat kecukupan dana BOS } \\
\text { untuk kegiatan operasional } \\
\text { Sekolah }\end{array}$ & 80 & 73 & Baik \\
\hline 10 & $\begin{array}{l}\text { Selama ini di SDIT Assalam } \\
\text { terjadi ketepatan waktu } \\
\text { penerimaan dana }\end{array}$ & 84 & 76 & Baik \\
\hline 11 & $\begin{array}{l}\text { Selama ini di SDIT Assalam } \\
\text { tidak ada pungutan/iuran terhadap } \\
\text { peserta didik untuk biaya } \\
\text { operasional }\end{array}$ & 65 & 59 & Cukup Baik \\
\hline 12 & $\begin{array}{l}\text { Selama ini di SDIT Assalam } \\
\text { iuran hanya dilakukan jika ada } \\
\text { kesepakatan antara pihak sekolah } \\
\text { dan orangtua, semisal infak. }\end{array}$ & 93 & 85 & Sangat Baik \\
\hline 13 & $\begin{array}{l}\text { Selama ini di SDIT Assalam } \\
\text { peserta didik dapat menyelesaikan } \\
\text { sekolahnya dengan tepat }\end{array}$ & 94 & 85 & Sangat Baik \\
\hline 14 & $\begin{array}{l}\text { Selama ini di SDIT Assalam } \\
\text { tidak ada peserta didik putus } \\
\text { sekolah karena alasan biaya }\end{array}$ & 89 & 81 & Baik \\
\hline
\end{tabular}




\begin{tabular}{|c|l|l|l|l|}
\hline 15 & $\begin{array}{l}\text { Selama ini di SDIT Assalam } \\
\text { semua peserta didik merupakan } \\
\text { tamatan SD/sederajat yang } \\
\text { langung melanjutkan ke SMP } \\
\text { tanpa menunda waktu terlebih } \\
\text { dahulu dengan alasan keberatan } \\
\text { biaya }\end{array}$ & 86 & 78 & Baik \\
\hline 16 & $\begin{array}{l}\text { Selama ini di SDIT Assalam ada } \\
\text { Sosialisasi mengenai dana BOS } \\
\text { yang diterima sekolah }\end{array}$ & 79 & 72 & Baik \\
\hline 17 & $\begin{array}{l}\text { Selama ini di SDIT Assalam } \\
\text { seluruh keperluan yang } \\
\text { berhubungan dengan proses } \\
\text { pembelajaran seperti buku } \\
\text { sumber, alat tulis dapat terpenuhi } \\
\text { oleh dana BOS }\end{array}$ & 77 & 70 & Baik \\
\hline 18 & $\begin{array}{l}\text { Selama ini di SDIT Assalam bila } \\
\text { ada pungutan/iuran di sekolah } \\
\text { jumlahnya hanya sedikit }\end{array}$ & 92 & 84 & Sangat Baik \\
\hline 19 & $\begin{array}{l}\text { Selama ini di SDIT Assalam bila } \\
\text { ada pungutan hanya berfungsi } \\
\text { sebagai sumber tambahan, } \\
\text { sedangkan biaya pokoknya } \\
\text { bersumber dari dana BOS. }\end{array}$ & 77 & 70 & Baik \\
\hline
\end{tabular}

Dari tabel tersebut dapat dilihat bahwa rata - rata jawaban responden pada variabel manfaat dana Bantuan Operasional Sekolah adalah yaitu $73 \%$ dari seluruh pertanyaan variabel X. Berdasarkan tabel 3.1 (tabel kriterai penilaian) 73\% berada pada rentang 68 - 83,9 dengan kriteria baik. Indikator dengan nilai persentase tertinggi yaitu pada item pertanyaan : Selama ini di SDIT Assalam peserta didik dapat menyelesaikan sekolahnya dengan tepat, dengan nilai persentase masing - masing $85 \%$ atas skor nilai yaitu 94 . Sedangkan item pertanyaan yang memperoleh skor terendah yaitu item pertanyaan : Selama ini di SDIT Assalam penggunaan dana BOS untuk pembelajaran dan ektrakulikuler dengan nilai persentase 52\% dan mendapat skor nilai yaitu 57.

Hasil pengamatan peneliti di SDIT Assalam menunjukan bahwa dana bantuan operasional sekolah digunakan untuk berbagai keperluan operasional sekolah. Hal itu dibuktikan dengan tercukupinya biaya pembelajaran dari dana bantuan operasional sekolah. Hal itu dilihat dari rekapan laporan dana bantuan operasional sekolah yang dibuat setiap triwulan oleh tim manajemen BOS. Kemudian dibuktikan juga dengan adanya berbagai fasilitas dalam proses 
belajar seperti alat tulis, sumber belajar (buku), adanya berbagai kegiatan ekstrakulikuler yang ada. Kegiatan ekstrakulikuler yang ada di SDIT Assalam Garut Kota yaitu : Pendidikan kepramukaan, olahraga, kesenian BTQ dan keagamaan. Adapun untuk hal iuran bulanan diperkuat dari hasil wawancara peneliti dengan bendahara di SDIT Assalam.

"Peserta didik tidak dibebankan biaya atau iuran bulanan yang diperuntukan keperluan alat tulis, sumber belajar dan kegiatan ekstrakulikuler adapun jika ada iuran tambahan seperti infak dan itu juga terlebih dahulu harus kesepakatan antara pihak sekolah dan pihak orangtua peserta didik dan jumlanya tidak mengikat".

Berdasarkan study dokumentasi yang dilakukan oleh peneliti, di SDIT Assalam tidak terdapat peserta didik yang drop out dengan alasan keberatan biaya pendidikan. Adapun terdapat mutasi murid itu karena alasan pindah sekolah.

Berikut rekapan laporan dana bantuan operasional sekolah SDIT Assalam untuk tahun 2014:

1 Pengembangan Perpustakaan

2 Kegiatan dalam rangka penerimaan siswa baru

3 Kegiatan pembelajaran dan ekstra kurikuler siswa

4 Kegiatan Ulangan dan Ujian

7.126 .000

5 Pembelian bahan-bahan habis pakai

2.312 .000

6 Langganan daya dan jasa

7 Perawatan sekolah 850.000

8 Pembayaran honorarium bulanan guru honorer dan tenaga kependidikan honorer

9 Pengembangan profesi guru

10 Membantu siswa miskin

11 Pembiayaan pengelolaan BOS

12 Pembelian perangkat komputer

13 Biaya lainnya jika seluruh komponen 1 s.d 12 telah terpenuhi pendanaannya dari BOS

Hasil analisis deskriptif terhadap hasil jawaban variabel Mutu Proses Pembelajaran yaitu: 


\begin{tabular}{|c|c|c|c|c|}
\hline No & Item Pertanyaan & $\begin{array}{c}\text { Jumlah } \\
\text { Skor }\end{array}$ & $\begin{array}{c}\text { Persentase } \\
(\%)\end{array}$ & Kriteria \\
\hline 1 & $\begin{array}{l}\text { Selama ini } r \\
\text { pembelajaran di SDIT } \\
\text { Assalam terdapat interaksi } \\
\text { positif antara pendidik dan } \\
\text { peserta didik. }\end{array}$ & 85 & 77 & Baik \\
\hline 2 & $\begin{array}{l}\text { Selama ini } r \text { proses } \\
\text { pembelajaran di SDIT } \\
\text { Assalam interaksi antar peserta } \\
\text { didik terjadi secara baik dan } \\
\text { komunikatif. }\end{array}$ & 83 & 75 & Baik \\
\hline 3 & $\begin{array}{l}\text { Selama ini di SDIT Assalam } \\
\text { lingkungan membantu peserta } \\
\text { didik dalam proses } \\
\text { pembelajaran. }\end{array}$ & 92 & 84 & Sangat Baik \\
\hline 4 & $\begin{array}{l}\text { Selama ini di SDIT Assalam } \\
\text { kegiatan pembelajaran } \\
\text { didukung oleh sumber belajar } \\
\text { yang cukup seperti buku } \\
\text { pelajaran. }\end{array}$ & 97 & 88 & Sangat Baik \\
\hline 5 & $\begin{array}{l}\text { Di SDIT Assalam lingkungan } \\
\text { sekolah membuat pendidik } \\
\text { dan peserta didik nyaman } \\
\text { belajar. }\end{array}$ & 92 & 84 & Sangat Baik \\
\hline 6 & $\begin{array}{l}\text { Di SDIT Assalam peserta } \\
\text { didik senantiasa memberikan } \\
\text { umpan balik dan mendukung } \\
\text { dalam proses pembelajaran. }\end{array}$ & 85 & 77 & Baik \\
\hline 7 & $\begin{array}{l}\text { Di SDIT Assalam suasana } \\
\text { belajar mengajar yang } \\
\text { membuat peserta didik } \\
\text { senang sehingga peserta didik } \\
\text { memusatkan perhatiannya } \\
\text { secara penuh pada belajar } \\
\text { sehingga waktu curah } \\
\text { perhatiannya (time on } \\
\text { task) tinggi. }\end{array}$ & 84 & 76 & Baik \\
\hline 8 & $\begin{array}{l}\text { Selama ini } r \\
\text { pembelajaran di SDIT } \\
\text { Assalam peserta didik } \\
\text { diperhadapkan pada masalah } \\
\text { kemungkinan-kemungkinan } \\
\text { baru, persoalan-persoalan } \\
\text { dilematis, dan paradoks } \\
\text { sesuai dengan tingkat usianya }\end{array}$ & 81 & 74 & Baik \\
\hline & $\begin{array}{lll}\text { Selama ini } & \text { proses } \\
\text { pembelajaran }^{\text {di }} & \text { SDIT }\end{array}$ & 93 & 85 & Sangat Baik \\
\hline
\end{tabular}




\begin{tabular}{|c|c|c|c|c|}
\hline 9 & 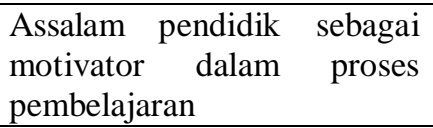 & & & \\
\hline 10 & $\begin{array}{l}\text { Selama ini proses } \\
\text { pembelajaran di SDIT } \\
\text { Assalam pendidik mendorong } \\
\text { dan memberi semangat pada } \\
\text { peserta didik untuk mencapai } \\
\text { prestasi. }\end{array}$ & 96 & 87 & Sangat Baik \\
\hline 11 & 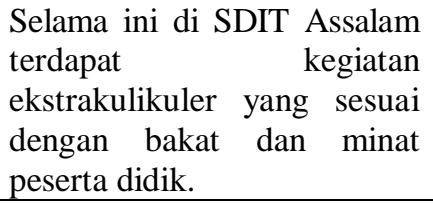 & 79 & 72 & Baik \\
\hline 12 & $\begin{array}{l}\text { Selama ini di SDIT Assalam } \\
\text { Terdapat ruang } \\
\text { pengembangan diri peserta } \\
\text { didik yang memiliki prestasi } \\
\text { unggulan. }\end{array}$ & 81 & 74 & Baik \\
\hline 13 & $\begin{array}{l}\text { Selama ini di SDIT Assalam } \\
\text { sekolah mendukung penuh } \\
\text { terhadap kemampuan prestasi } \\
\text { peserta didik sesuai dengan } \\
\text { bidangnya. }\end{array}$ & 81 & 74 & Baik \\
\hline \multicolumn{3}{|c|}{ Rata - rata } & 79 & Baik \\
\hline
\end{tabular}

Dari tabel diatas dapat disimpulkan bahwa mutu proses pembelajaran di SDIT Assalam mendapat nilai rata - rata 79. Berdasarkan tabel termasuk dalam kriteria baik. Skor tertinggi ada pada item pertanyaaan Selama ini di SDIT Assalam kegiatan pembelajaran didukung oleh sumber belajar yang cukup seperti buku pelajaran dengan nilai prosentase $88 \%$. Sedangkan untuk skor terendah yaitu item pertanyaan Selama ini di SDIT Assalam terdapat kegiatan ekstrakulikuler yang sesuai dengan bakat dan minat peserta didik dengan nilai prosentase $72 \%$.

Hasil tabel diatas kemudian diperkuat dengan hasil wawancara dan observasi yang dilakukan oleh peneliti. Melalui observasi atau pengamatan langsung, peneliti melihat bahwa proses pembelajaran di SDIT Assalam ditunjang oleh fasilitas media dan sumber pembelajaran yang cukup hal ini ditandai dengan adanya sarana lab IPA (KIT IPA), alat dan bahan praktek untuk mata pelajaran alam dan sosial, media pembelajaran seperti komputer internet, buku pelajaran yang cukup, sarana perpustakaan yang cukup serta berbagai media dan daya 
dukung sehingga proses pembelajaran menjadi menarik, menantang dan terjadi proses interaktif yang positif antara pendidik dan peserta didik.

Hasil wawancara dengan kepala sekolah menyebutkan bahwa di SDIT Assalam terdapat 4 jenis ekstrakulikuler yaitu Pendidikan Kepramukaan, BTQ, kesenian dan Olahraga. Sedangkan untuk pengembangan diri pihak sekolah menyelengarakan praktik ibadah dengan merutinkan solat duha dan solat duhur berjamaah untuk setiap harinya (Untuk Duha kecuali senin karena jadwal upacara dan kecuali Jumat karena jadwal jumsih).

\section{Daftar Pustaka}

Hadis dan Nurhayati. 2010. Manajemen Mutu Pendidikan. Bandung: Alfabeta

Nana, S.S, Ayi N.J, dan Ahman. 2006. Pengendalian Mutu Pendidikan

Sekolah Menengah (Konsep, Prinsip dan Instrumen). Bandung :Rafika Aditama.

Peraturan Pemerintah No 19 tahun 2005 tentang Standar Nasional Pendidikan (SNP)

Petunjuk Teknis Penggunaan Dana BOS. Kemendikbud 